\title{
Quality assessment of the manufacture of new ripened soft cheese by Geotrichum candidum: physico-chemical and technological properties
}

\author{
Henrique JASTER ${ }^{1}$, Priscila JUDACEWSKI ${ }^{1}$, Jéssica Caroline Bigaski RIBEIRO ${ }^{2}$, \\ Acácio Antonio Ferreira ZIELINSKI ${ }^{1}$, Ivo Mottin DEMIATE ${ }^{1,2}$, Paulo Ricardo LOS ${ }^{1}$, Aline ALBERTI ${ }^{1,2}$, \\ Alessandro NOGUEIRA ${ }^{1,2 *}$
}

\begin{abstract}
A new type of ripened soft cheese by Geotrichum candidum was manufactured with pasteurized milk from Jersey and Holstein cow breeds. The physico-chemical (moisture, $\mathrm{pH}$, acidity, protein, lipids and ash) and technological parameters (proteolysis, texture profile and color) during 21 days of ripening cheese (surface, center and whole), were evaluated. The differences in the cheese produced with Holstein cow milk were related to increased proteolysis (tyrosine and acid-soluble nitrogen) and the influence of the $a^{*}$ and $b^{*}$ color parameters. The cheeses prepared with Jersey cow milk showed a high fat content and lower proteolysis, which had a significant effect on the instrumental texture profile. Using chemometrics and two-way ANOVA was possible to distinguish the cheeses based on the breed of cow and ripening time. After two weeks, the cheeses already presented characteristics of the ripening by G. candidum.
\end{abstract}

Keywords: ripened soft cheese; chemometrics; surface-ripening; proteolysis; texture profile.

Practical Application: The Brazilian cheese market is growing. However, there is few information about the manufacture of ripened cheeses and quality characteristics. The article presents the detailed manufacturing protocol of a new ripened cheese by Geotrichum candidum. This yeast provides distinct characteristics in the cheeses mainly for gastronomic application. This research will be useful in the scientific sector and in the dairy industry. Therefore, the cheeses, with only two to three weeks of ripening, is one more way of adding value to the milk and contributing to the diversity of Brazilian cheeses.

\section{Introduction}

Geotrichum candidum is a surface yeast that positively affects the characteristics (appearance, texture, taste and aroma) of several mold-'ripened cheeses, such as Camembert, Munster, Limburger, Saint Marcellin and Livarot (soft cheeses), as well as Reblochon, Saint Nectaire and Armada (semi-hard cheeses) (Larpin et al., 2006; Pottier et al., 2008; Cogan et al., 2014). The G. candidum can be used in cheeses that are prepared with unpasteurized milk, and especially when prepared with pasteurized milk, since it enhances sensory characteristics that are related to raw milk ripened cheeses (Boutrou \& Guéguen 2005; Mourgues et al., 1983) resulting on the increase of its popularity among consumers of several countries.

In the cheese manufacturing, commercial strains of G. candidum can be added to the milk, to the brine or sprayed in the cheese aiming to colonize the surface of the cheeses during the first week of ripening (Boutrou et al., 2006). After 1 or 2 weeks, the population become stable with about $10^{5}-10^{7} \mathrm{TFU}$ (thallus forming units) per gram of cheese (Pottier et al., 2008; Molimard et al., 1995). In the cheese, their growth provides a uniform velvety-white mold on the surface (Boutrou \& Guéguen, 2005). The G. candidum grows in a wide temperature range $\left(5\right.$ to $\left.38^{\circ} \mathrm{C}\right)$ with optimum around $25^{\circ} \mathrm{C}$. The $\mathrm{pH}$ of the cheese during preparation (4.4 to 6.7 ) has little influence on the growth of G. candidum (Van den Tempel \& Nielsen, 2000). However, wild and commercial strains may tolerate only 1 to $5 \%$ of salt (Boutrou \& Guéguen, 2005).

In the cheeses, G. candidum is responsible for metabolize the galactose (cheeses manufactured with thermophilic lactic acid bacteria) and the lactic acid (lactate) as the main source of energy (Monnet et al., 2015; Aziza et al., 2008). After a few days of ripening, the higher level of the lactate in the surface is metabolized by $G$. candidum, promoting its migration from the core to the outside of the cheese (Larpin et al., 2006). In addition, G. candidum releases ammonia during the metabolism of amino acids, which diffuses from the outside in with the increase of the $\mathrm{pH}$ in the surface (McSweeney, 2017; Boutrou \& Guéguen, 2005). Therefore, at the final of the processing, the $\mathrm{pH}$ in the surface can reach to a value higher than 7.5 for some ripened cheeses (Monnet et al., 2015). Furthermore, during cheese ripening, G. candidum provides highly active proteases (mainly peptidases), with optimal $\mathrm{pH}$ values ranging from 5.5 to 6.0 (releasing peptides and amino acids), and lipases which optimal $\mathrm{pH}$ range from 5.5 to 7.0 (releasing free fatty acids). These enzymes

${ }^{1}$ Programa de Pós-graduação em Ciência e Tecnologia de Alimentos, Universidade Estadual de Ponta Grossa - UEPG, Ponta Grossa, PR, Brasil

${ }^{2}$ Departamento de Engenharia de Alimentos, Universidade Estadual de Ponta Grossa - UEPG, Ponta Grossa, PR, Brasil

*Corresponding author: alessandronog@yahoo.com.br 
contribute releasing energy substrates and development of the distinct flavor, texture and thickness of the rind (Monnet et al., 2015; Sacristán et al., 2012; Marcellino et al., 2001).

Holstein and Jersey cow milks are commonly used in cheese manufacturing and have different characteristics between them that may affect the cheese ripening (Blake et al., 2012). Therefore, this study aimed to evaluate the effect of the use of pasteurized milk from Holstein and Jersey cow breeds on the physical-chemical and related properties in a new cheese ripened by G. candidum.

\section{Materials and methods}

\subsection{Materials}

Holstein cow milk was provided by the Capão da Onça School Farm (FESCON) of the State University of Ponta Grossa (UEPG), located in the city of Ponta Grossa (Paraná, Brazil $\left.25^{\circ} 05^{\prime} 42^{\prime \prime} \mathrm{S}, 500^{\circ} 09^{\prime} 43^{\prime \prime} \mathrm{W}\right)$. Jersey cow milk was provided by a milk producer from the city of Castro (Paraná, Brazil $24^{\circ} 47^{\prime} 28^{\prime \prime} \mathrm{S}, 50^{\circ} 00^{\prime} 43^{\prime \prime} \mathrm{W}$ ).

Thermophilic culture (Streptococcus thermophilus and Lactobacillus delbrueckii subsp. bulgaricus, YO-MIX 495 LYO, Danisco, Canada) were used as lactic fermentation starters. Geotrichum candidum (Choozit's 13, Danisco, Canada) was used as surface culture. Calcium chloride (Biotec, USA), curd-based chymosin and bovine pepsin (HA-LA 2154 IMCU, Chr. Hansen, Brazil), food grade sodium chloride (Sal Marinho Cisne, Brazil) and annatto colorant (Coalhopar FBE-U70, Brazil) were used in the manufacture of the cheeses. All the reagents used in the experiments were of analytical grade. The aqueous solutions were prepared using ultra-pure water (Milli-Q, Millipore, Brazil).

\subsection{Methods}

\section{Cheese manufacture}

The new manufacturing protocol of cheeses ripened with G. candidum was tested and improved by cheesemakers in the pilot plant of the Technological School of Milk and Cheese of the Campos Gerais region (ETLQueijos, UEPG, Ponta Grossa, Brazil). The Holstein cow milk and the Jersey cow milk (three batches of $100 \mathrm{~L}$ for each cow breed milk) were pasteurized at $73{ }^{\circ} \mathrm{C}$ for 15 seconds (plate pasteurizer, Mec Milk -21, Brazil). In sequence, the Jersey cow milk ( $\mathrm{pH} 6.65 \pm 0.01$; lipid content $33.7 \pm 0.6 \mathrm{~g} / \mathrm{L}$; protein content $36.6 \pm 0.4 \mathrm{~g} / \mathrm{L}$; non-fat dry extract $92.3 \pm 0.5 \mathrm{~g} / \mathrm{L}$ and somatic cell count $\left.269 \pm 26 \times 10^{3} \mathrm{cell} / \mathrm{mL}\right)$ and Holstein cow milk ( $\mathrm{pH} 6.68 \pm 0.01$; lipid content $25 \pm 3 \mathrm{~g} / \mathrm{L}$; protein content $31.7 \pm 0.7 \mathrm{~g} / \mathrm{L}$; non-fat dry extract $83 \pm 2 \mathrm{~g} / \mathrm{L}$ and somatic cell count $274 \pm 34 \times 10^{3} \mathrm{cell} / \mathrm{mL}$ ) and cooled to $34^{\circ} \mathrm{C}$ in stainless steel tanks (AISI 304). To the milk were added $0.01 \mathrm{~g} / \mathrm{L}$ of thermophilic lactic acid cultures and $0.4 \mathrm{~mL} / \mathrm{L}$ of a solution of $500 \mathrm{~g} / \mathrm{L}$ calcium chloride (Synth, Brazil). After $30 \mathrm{~min}$ ( $\mathrm{pH} 6.54$ - 6.56) the rennet $(0.016 \mathrm{~g} / \mathrm{L})$ was added. The curd was cut with the aid of a curd-cutting harp in vertical and horizontal directions ( $2 \mathrm{~cm}$ cubes), followed by slow stirring for $30 \mathrm{~min}$ until the perception of the desired texture of the curd. In this period of agitation, the temperature was controlled until it reached $36^{\circ} \mathrm{C}$.

The cheese curds were transferred into high-density polyethylene molds (140 mm diameter and $100 \mathrm{~mm}$ height,
Jandaplast RP-500, Brazil), using cheese cloth to assist the whey drainage. During the pressing $(2.0 \mathrm{~kg}$ used per cheese for $6 \mathrm{~h})$, two turns were made (after 30 and $60 \mathrm{~min}$ ). The $\mathrm{pH}$ of the whey during pressing was $6.42-6.44$. After pressing, the cheeses were kept in the molds at $10.0 \pm 0.5^{\circ} \mathrm{C}$ for $12 \mathrm{~h}$ for drying and pre-ripening. The cheeses were immersed in $20^{\circ} \mathrm{Brix}$ brine for $60 \mathrm{~min}$ at $10^{\circ} \mathrm{C}$.

The cheese ripening was initiated at $\mathrm{pH}$ 5.10-5.15. The $G$. candidum was inoculated by spraying $(9.0 \mathrm{~g} / \mathrm{L}$ sodium chloride solution, containing 3.0-5.0 $\times 10^{4}$ spores $\left./ \mathrm{mL}\right)$. The relative humidity $(95 \pm 2 \%)$ and the temperature $\left(16.0 \pm 0.5^{\circ} \mathrm{C}\right)$ were controlled for seven days. This temperature at the beginning of ripening promotes the growth and deacidifying of the surface by the G. candidum. After this period, the cheeses were washed with brine ( $9.0 \mathrm{~g} / \mathrm{L}$ sodium chloride) to control the development of "graisse" (a surface layer of G. candidum with fatty aspect) and to prevent the growth of contaminant molds (Monnet et al., 2015). The cheeses were immersed in annatto solution to develop a dark orange color rind. Following, the samples were maintained for two weeks at $12 \pm 0.5^{\circ} \mathrm{C}$ and relative humidity $\geq 95 \pm 2 \%$; they were turned every two days. The G. candidum that grew in the surface (stained by annatto) created a thin white layer that left the cheese with its characteristic orange color.

The experiments were carried out in three replicates ( $100 \mathrm{~L}=36$ cheeses $\times 3=108$ cheeses samples) for both the Jersey and Holstein cow milk. Analytical monitoring was performed in the cheeses with 1, 7, 14 and 21 days of ripening. On each date of analysis, four cheeses were removed at random from the ripening chamber: two were divided into surface and center portions, and two were analyzed in full (whole cheese). The "surface" portion (upper, lower and side parts) corresponded to a 3-4 mm layer and the "center" was the remainder of the cheese. The whole cheese and the separate fractions were ground and homogenized in a food processor (Philips Walita, model RI 7620, Brazil) and immediately analyzed.

\section{Composition analysis}

Milk

The determinations of $\mathrm{pH}$ (Hanna, model pH 21, Brazil) and acidity were performed as described by the AOAC (Association of Official Analytical Chemists International, 2016). The contents of solids were measured gravimetrically after the samples were dried to constant weight at $105^{\circ} \mathrm{C}$ (Instituto Adolfo Lutz, 2008). The lipid contents were determined by Gerber butyrometer, and total nitrogen by the Kjeldahl method using a conversion factor of 6.38 for crude protein (Association of Official Analytical Chemists International, 2016). The somatic cell count was performed using a DCC DeLaval cell counter (Tumba, Sweden).

\section{Cheese}

The samples were ground in a processor (Philips Walita, model RI 7620, Barueri, São Paulo). Titratable acidity, crude protein, solid and moisture contents were measured as described in classic methodology for cheeses (Association of Official Analytical Chemists International, 2016; Instituto Adolfo Lutz, 
2008). Lipid content was determined using a Gerber butyrometer specifically used for cheese analysis.

\section{Monitoring of proteolysis}

Proteolysis was determined by soluble nitrogen at $\mathrm{pH} 4.6$ (acid soluble nitrogen - ASN) (Lynch \& Barbano, 1999) and soluble nitrogen in $12 \%$ trichloro acetic acid (non-protein nitrogen - NPN) (Association of Official Analytical Chemists International, 2016). The calculations of the extent of the proteolysis index (EPI) which reflects the percent of decomposed protein molecules, mostly to large peptides and the depth of proteolysis (DPI) indicated the percent to which these large peptides are degraded into smaller molecules, were carried out as described by De Rensis et al. (2009). Proteolysis was also assessed by the concentration of tyrosine, using the method proposed by Vakaleris \& Price (1959). The results were expressed as percentages of proteolysis during the ripening period ([end value ${ }_{21 \mathrm{~d}}-$ initial value $_{1 \mathrm{~d}}$ / initialvalue $\left._{1 \mathrm{~d}} \times 100\right)$.

\section{Color measurements}

The color parameters of the cheeses were analysed by reflectance using a MiniScan EZ colorimeter (Hunter Lab, Reston, Virginia, USA). The readings (six repetitions) were taken from the surface and the center of the cheeses, and then the values for $L^{*}$ (lightness; $100=$ white, $0=$ black), $a^{*}$ (chromaticity; + red; - green) and $b^{\star}$ (chromaticity; + yellow; - blue) were recorded. The hue angle $\left(h^{*}\right)$ was calculated as the inverse tangent of the ratio $b^{*} / a^{*}$, due to the combination of $a^{\star}$ and $b^{\star}$ gives a better indication of color than their individual values (Wadhwani \& Mcmahon, 2012).

\section{Texture profile analysis (TPA)}

Cylinders of $2 \mathrm{~cm}$ diameter and $2 \mathrm{~cm}$ height were taken from the cheeses to obtain six replicates per sample. The determination of the texture profile was performed at $25^{\circ} \mathrm{C}$ in a TA-XTPlus Texture Analyzer (Stable Micro Systems, Godalming, UK) using a $36 \mathrm{~cm}$ diameter aluminium cylindrical probe (P-36). The test speed was $0.8 \mathrm{~mm} / \mathrm{s}$, with dual compression of $30 \%$ of the initial height of the sample (Marinho et al., 2015).

\subsection{Statistical analysis}

The data were presented as mean \pm standard deviation (SD). Firstly, all the variables had their normality checked (Shapiro-Wilk's test), and the differences between the samples were assessed by Student's test or one-way analysis of variance (ANOVA) followed by Fisher's LSD post hoc test. Pearson's correlation was used to evaluate the strength of correlation between the evaluated parameters. A p-value below 0.05 was significant (Marinho et al., 2015). Two-way ANOVA was performed on the data to study the effects of the cow breeds and the period of ripening on the physico-chemical composition and instrumental parameters of the ripening by $G$. candidum. A chemometric application, which was composed of principal component analysis (PCA) and hierarchical cluster analysis (HCA), was implemented. Firstly, all the variables were auto scaled to standardize the statistical importance of all the responses (Zielinski et al., 2014).

PCA was performed to analyze the correlation between the cheeses made from Holstein and Jersey cow milk during the ripening time with $G$. candidum. A $2 \mathrm{D}$-scatter plot was used to distinguish the differences between the samples obtained by the PCA results. Lastly, HCA was performed to assess the similarities between the cheeses. The similarities were calculated by Euclidean distance, and the Ward hierarchical agglomerative method was used to cluster the samples (Zielinski et al., 2014). The three suggested clusters were compared, the homogeneity of variance was checked by Levene's test, and one-way ANOVA, and Fisher's LSD post hoc tests were applied to verify the differences between the clusters. For the variables that did not present homogeneous variances $(p>0.05)$ the Kruskal-Wallis test was used. All the statistical analyses were performed using Statistica 13.2 software (Stat Soft Inc. South America, Tulsa, OK, USA).

\section{Results and discussion}

\subsection{Characteristics and composition of the cheeses}

In twenty-one (21) days of ripening, the cheeses $(n=10)$ were cylindrical in shape (diameter of $100 \pm 2 \mathrm{~mm}$ on average) with an average height of $40 \pm 2 \mathrm{~mm}$ and weight of $304 \pm 27 \mathrm{~g}$. The cheeses were classified according to purpose by Bylund (2015) and they ranged from medium (36-45.9\%) to high (46-54.9\%) moisture content; as soft (moisture on a fat-free basis (MFFB) $>67 \%$ ) and high-fat (fat on a dry basis (FDB) > 60\%) cheeses (Table 1), typical contents for cheese ripened by G. candidum (Martin et al., 1997). The moisture content during the ripening of cheeses evidenced a certain fluctuation among samples for the two cheeses evaluated (from Holstein and Jersey milk). However, in most of the analysis points, the values showed not significant differences $(p>0.05)$ (Table 1$)$. The cheeses produced with Holstein cow milk (whole cheese) had an increase (not significant $p>0.05$ ) of ash content, until twenty-one (21) days of ripening (ash $x$ ripening, $r=0.67, p<0.05$ ). The ash content increase significantly $(p<0.05)$ on the surface of the cheeses during ripening (Table 1). Probably due to the mineral displacement into the curd to compensate the precipitation of calcium salts in the surface of the cheeses due to increases in $\mathrm{pH}$ (McSweeney, 2017). In addition, the salting process (first day) and annatto painting (seventh day of ripening) can increase the ash content on the surface.

The cheeses made from Jersey cow milk (lipid content in milk of $33.7 \mathrm{~g} / \mathrm{L}$ ) showed a $28 \%$ higher lipid content than in the cheeses made with Holstein cow milk (lipid content in milk $24.7 \mathrm{~g} / \mathrm{L}$ ) in the whole fraction (Table 1). Practically all the lipid fraction of the milk is retained in the casein gel (McSweeney, 2017). In our study, the cheese prepared with Jersey cow milk showed a lower lipid content (Table 1) than French Camembert, a soft cheese (minimum of $45 \mathrm{~g} / 100 \mathrm{~g}$ in dry matter) (France, 2008). The lipid content in cheeses is important for the development of the aromatic compounds (secondary biochemical events of ripening), mainly by milk lipases [lipoprotein lipase (LPL)] released by $G$. candidum. 
Jaster et al.

Table 1. Physico-chemical of ripened cheese by G. candidum elaborated with cow milk of Holstein and Jersey breeds.

\begin{tabular}{|c|c|c|c|c|c|c|c|}
\hline \multirow{2}{*}{$\begin{array}{c}\text { Parameters } \\
(\mathrm{g} / \mathrm{kg})\end{array}$} & \multirow{2}{*}{$\begin{array}{l}\text { Dairy } \\
\text { Cows }\end{array}$} & \multirow{2}{*}{$\begin{array}{c}\text { Fraction } \\
\text { cheese }\end{array}$} & \multicolumn{4}{|c|}{ Period of ripening (days) } & \multirow[b]{2}{*}{$p$} \\
\hline & & & 1 & 7 & 14 & 21 & \\
\hline \multirow[t]{5}{*}{ Moisture } & Holstein & Center & $595 \pm 25^{\mathrm{aA}}$ & $487 \pm 12^{\mathrm{bA}}$ & $572 \pm 7^{\mathrm{aA}}$ & $578 \pm 7^{\mathrm{aA}}$ & * \\
\hline & & Surface & $499 \pm 18^{\mathrm{aB}}$ & $517 \pm 23^{\mathrm{aA}}$ & $503 \pm 6^{\mathrm{aBC}}$ & $428 \pm 14^{\mathrm{bD}}$ & * \\
\hline & & Whole & $603 \pm 43^{\mathrm{aA}}$ & $507 \pm 5^{\mathrm{bcA}}$ & $545 \pm 20^{\mathrm{bAB}}$ & $484 \pm 9^{c \mathrm{C}}$ & * \\
\hline & Jersey & Center & $485 \pm 32^{\mathrm{B}}$ & $489 \pm 30^{\mathrm{A}}$ & $496 \pm 46^{\mathrm{BC}}$ & $520 \pm 14^{\mathrm{B}}$ & ns \\
\hline & & Surface & $573 \pm 11^{\mathrm{aA}}$ & $435 \pm 11^{\mathrm{bB}}$ & $475 \pm 6^{\mathrm{bC}}$ & $468 \pm 32^{\mathrm{bC}}$ & * \\
\hline$P$ & & & * & * & * & * & \\
\hline \multirow[t]{4}{*}{ Ash } & Holstein & Center & $29.5 \pm 0.6^{\mathrm{aBC}}$ & $30 \pm 1^{\mathrm{a}}$ & $27.1 \pm 0.7^{\mathrm{bD}}$ & $22.1 \pm 0.1^{\mathrm{cE}}$ & * \\
\hline & & Surface & $35.2 \pm 0.4^{\mathrm{bA}}$ & $32 \pm 2^{\mathrm{e}}$ & $38.8 \pm 0.2^{\mathrm{dA}}$ & $38.7 \pm 1^{\mathrm{aA}}$ & * \\
\hline & & Whole & $30.0 \pm 0.3^{\text {bсB }}$ & $34.6 \pm 0.4^{\mathrm{d}}$ & $33.6 \pm 2.1^{\mathrm{eB}}$ & $37.3 \pm 0.9^{\mathrm{aA}}$ & * \\
\hline & Jersey & Center & $28 \pm 1^{\mathrm{CD}}$ & $34 \pm 9$ & $27.8 \pm 2.5^{\mathrm{CD}}$ & $25.3 \pm 0.2^{\mathrm{D}}$ & ns \\
\hline \multirow{5}{*}{ Lipids } & & Surface & $243 \pm 6^{C}$ & $240 \pm 5.0^{\mathrm{C}}$ & $238 \pm 10.4^{\mathrm{C}}$ & $235 \pm 13^{\mathrm{C}}$ & ns \\
\hline & & Whole & $235 \pm 5^{\mathrm{C}}$ & $228 \pm 7.6^{\mathrm{C}}$ & $230 \pm 5^{\mathrm{C}}$ & $236 \pm 6^{C}$ & ns \\
\hline & Jersey & Center & $310 \pm 10^{\mathrm{B}}$ & $305 \pm 13.3^{\mathrm{B}}$ & $315 \pm 13.2^{\mathrm{A}}$ & $297 \pm 8^{\mathrm{B}}$ & ns \\
\hline & & Surface & $327 \pm 6^{\mathrm{aA}}$ & $307 \pm 5.7^{\text {bв }}$ & $295 \pm 5^{\mathrm{cB}}$ & $293 \pm 6^{\mathrm{cB}}$ & * \\
\hline & & Whole & $330 \pm 10^{\mathrm{A}}$ & $323 \pm 5.7^{\mathrm{A}}$ & $322 \pm 2.9^{\mathrm{A}}$ & $328 \pm 8^{A}$ & ns \\
\hline$P$ & & & * & * & * & * & \\
\hline \multirow[t]{4}{*}{ Protein } & Holstein & Center & $148 \pm 2^{\mathrm{cB}}$ & $176 \pm 16.9^{\mathrm{abB}}$ & $159 \pm 79^{\mathrm{bcE}}$ & $193 \pm 3^{\mathrm{aB}}$ & * \\
\hline & & Surface & $184 \pm 2^{\mathrm{bA}}$ & $184 \pm 2.2^{\mathrm{bB}}$ & $251 \pm 15^{\mathrm{aA}}$ & $191 \pm 16^{\mathrm{bB}}$ & * \\
\hline & & Whole & $142 \pm 2^{\mathrm{cC}}$ & $179 \pm 8.1^{\mathrm{bB}}$ & $183 \pm 2^{\mathrm{bD}}$ & $197 \pm 7^{\mathrm{aB}}$ & * \\
\hline & Jersey & Center & $181 \pm 1^{\mathrm{bA}}$ & $186 \pm 3.0^{\text {ьв }}$ & $200 \pm 1^{\mathrm{aC}}$ & $184 \pm 9^{\text {ьв }}$ & * \\
\hline \multirow{3}{*}{ NPN } & Jersey & Center & $1.6 \pm 0.1^{\mathrm{cB}}$ & $2.2 \pm 0.01^{\mathrm{bB}}$ & $2.4 \pm 0.4^{\mathrm{bC}}$ & $4.4 \pm 0.2^{\mathrm{aD}}$ & * \\
\hline & & Surface & $0.60 \pm 0.01^{\mathrm{dC}}$ & $2.3 \pm 0.2^{\mathrm{cB}}$ & $3.9 \pm 0.1^{\mathrm{bB}}$ & $6.1 \pm 0.1^{\mathrm{aB}}$ & * \\
\hline & & Whole & $0.10 \pm 0.01^{\mathrm{dD}}$ & $0.4 \pm 0.01^{\mathrm{cC}}$ & $0.70 \pm 0.01^{\mathrm{bD}}$ & $1.20 \pm 0.01^{\mathrm{aE}}$ & * \\
\hline$P$ & & & * & * & * & * & \\
\hline \multirow[t]{6}{*}{ ASN } & Holstein & Center & $1.20 \pm 0.01^{\mathrm{bA}}$ & $0.80 \pm 0.01^{\mathrm{cB}}$ & $1.5 \pm 0.1^{\mathrm{aCD}}$ & $0.80 \pm 0.01^{\mathrm{cC}}$ & * \\
\hline & & Surface & $1.0 \pm 0.2^{\mathrm{cA}}$ & $0.90 \pm 0.01^{\mathrm{cB}}$ & $3.8 \pm 0.5^{\mathrm{aA}}$ & $2.0 \pm 0.2^{\mathrm{bB}}$ & * \\
\hline & & Whole & $1.0 \pm 0.2^{\mathrm{cA}}$ & $0.90 \pm 0.01^{\mathrm{cB}}$ & $2.5 \pm 0.2^{\mathrm{aB}}$ & $1.8 \pm 0.1^{\mathrm{bB}}$ & * \\
\hline & Jersey & Center & $0.9 \pm 0.2^{\mathrm{bA}}$ & $1.00 \pm 0.01^{\mathrm{bB}}$ & $1.00 \pm 0.01^{\mathrm{bD}}$ & $2.0 \pm 0.3^{\mathrm{aB}}$ & * \\
\hline & & Surface & $0.5 \pm 0.1^{\mathrm{cB}}$ & $1.7 \pm 0.4^{\mathrm{bA}}$ & $1.8 \pm 0.2^{\mathrm{bC}}$ & $3.9 \pm 0.5^{\mathrm{aA}}$ & * \\
\hline & & Whole & $0.60 \pm 0.01^{\mathrm{cB}}$ & $1.2 \pm 0.1^{\mathrm{bB}}$ & $1.40 \pm 0.01^{\mathrm{bD}}$ & $4.5 \pm 0.3^{\mathrm{aA}}$ & * \\
\hline$P$ & & & * & * & * & * & \\
\hline \multirow[t]{6}{*}{ Tyrosine } & Holstein & Center & $169 \pm 11^{\mathrm{bA}}$ & $193 \pm 14^{\mathrm{bC}}$ & $436 \pm 26^{\mathrm{bD}}$ & $1743 \pm 128^{\mathrm{aCD}}$ & * \\
\hline & & Surface & $149 \pm 6^{\mathrm{cA}}$ & $402 \pm 22^{\mathrm{cA}}$ & $3007 \pm 44^{\mathrm{bA}}$ & $5460 \pm 272^{\mathrm{aA}}$ & * \\
\hline & & Whole & $100 \pm 15^{c C}$ & $232 \pm 19^{\mathrm{cB}}$ & $1670 \pm 84^{\mathrm{bB}}$ & $4707 \pm 65^{\mathrm{aB}}$ & * \\
\hline & Jersey & Center & $83 \pm 34^{\mathrm{cC}}$ & $154 \pm 14^{\mathrm{cD}}$ & $471 \pm 31^{\mathrm{bD}}$ & $896 \pm 55^{\mathrm{aE}}$ & * \\
\hline & & Surface & $141 \pm 17^{\mathrm{dAB}}$ & $389 \pm 16^{\mathrm{cA}}$ & $1561 \pm 81^{\mathrm{bB}}$ & $2031 \pm 148^{\mathrm{aC}}$ & * \\
\hline & & Whole & $113 \pm 4^{\mathrm{cBC}}$ & $240 \pm 12^{\mathrm{cB}}$ & $687 \pm 179^{\mathrm{bC}}$ & $1671 \pm 52^{\mathrm{aD}}$ & * \\
\hline$P$ & & & * & * & * & * & \\
\hline
\end{tabular}

Note: Different lowercase letters in the same row indicate significant differences between days of ripening (Fisher's test, ${ }^{\star} p<0.05$ ). Different capital letters in the same column indicate significant differences between cheeses elaborated with cow milk breeds Holstein or Jersey (Fisher's test, ${ }^{*} p<0.05$ ). NPN: Non-protein nitrogen; ASN: Nitrogen soluble acid; ns: indicates no significant difference. 


\subsection{Proteolysis of the cheeses}

No significant differences $(p>0.05)$ were found in the protein content between cow breeds and their cheeses fractions until 21 days of ripening (Table 1 ). The extent of the proteolysis index (EPI) was significantly $(p<0.05)$ higher in the surface (21 days of ripening), and the NPN, ASN and tyrosine contents increased during ripening ( $N P N \mathrm{x}$ ripening, $r=0.87$, ASN x ripening, $r=0.76$, tyrosine $\mathrm{x}$ ripening, $r=0.79, p<0.01$ ) (Table 1 ).

The use of lactic acid by G. candidum raises the surface $\mathrm{pH}$ of the cheese (6.1-6.5) and stimulates the action of plasmin (milk endoproteinase), which enhances the proteolysis in the rind (McSweeney, 2017). On the other hand, the proteolysis in the center of the cheese was lower due to the difficulty of the enzyme diffusion.

Furthermore, the extent of the proteolysis (EPI) was significantly $(p<0.05)$ higher in the cheeses manufactured with Holstein cow milk after 14 days of ripening (Table 1 and Figure 1a) and that could be explained by the high content of plasmin found in this milk when compared with the Jersey cow milk (Bastian et al., 1991; Schaar, 1985). The biological activity of plasmin resists the pasteurization temperature, which affects the ripening process (Denis et al., 2001). Castellote et al. (2015) also observed that the cheeses ripened by G. candidum showed a beginning of proteolysis after 14 days and an extensive proteolysis after 20 days of ripening. The depth of proteolysis (DPI) in a cheese is mainly determined by the action of enzymes from the lactic acid bacteria starter (McSweeney, 2017). The cheeses (surface and center) showed the same DPI during the ripening (Figure 1b).

\subsection{Texture of the cheeses}

The changes in the instrumental texture parameters during ripening may have been related to proteolysis, predominantly after seven (7) days of ripening, when the greater changes were observed (Table 2). All texture parameters showed significant differences $(p<0.05)$ during the ripening (hardness $x$ ripening, $r=-0.79$; springiness $x$ ripening, $r=-0.95$; cohesiveness $x$ ripening, $r=-0.93$; gumminess $x$ ripening, $r=-0.80$; chewiness $x$ ripening, $r=-0,81$; resilience $x$ ripening, $r=-0.95$ ). The main softening of the cheeses made with Holstein or Jersey cow milk occurred from day one to day 14 of ripening. All the texture parameters showed decreasing values (Table 2 ) as the proteolysis increased within the ripening time (springiness $x N P N, r=-0.79$; springiness $x A S N$, $r=-0.82$; cohesiveness $x$ NPN, $r=-0.75$; cohesiveness $x$ ASN, $r=-0.81$; resilience $x$ NPN, $r=-0.79$; resilience $x A S N, r=-0.77$; resilience $x$ tyrosine, $r=-0.72$ ). Thus, the growth of $G$. candidum could be the principal factor that affected the texture (Molimard et al., 1995; Boutrou et al., 2006).

\subsection{Color of the cheeses}

The results of this study showed a decrease in brightness $\left(L^{*}\right)$ in the cheese (browning) during ripening $\left(L^{*} \mathrm{x}\right.$ ripening, $r=-0.62, p<0.05$ ) (Table 3 ). After seven days of ripening the annatto colorant was added to improve the external appearance of the cheese (Dufossé et al., 2005). This procedure is especially used in manufacture of industrial Reblochon cheese. There was a significantly $(p<0.05)$ increase in the $a^{*}$ parameter $[\mathrm{red}(+)$ to green (-)] on the surface (rind). As time passed, this red color tended to migrate towards the center, reducing the $L^{*}$ parameter $\left(a^{*} \times L^{*}, r=-0.82, p<0.05\right)$ and increasing the $b^{*}$ parameter [yellow $(+)$ blue $(-)$ ] $\left(a^{*} \times b^{*}, r=0.93, p<0.01\right)$ on the surface and in the center of the cheese. In addition, the surface growth of $G$. candidum produced a fine white biomass layer, which decreased the intensity of the red color. The hue angle $\left(h^{*}\right)$ suggested a coloration in the surface (rind) between light yellow (the cheese made with Jersey cow milk), light orange (the cheese made with Holstein cow wilk), and yellow in the center (for both cheeses) (Table 3). Therefore, the addition of the colorant on the surface positively affected the color of the cheese.

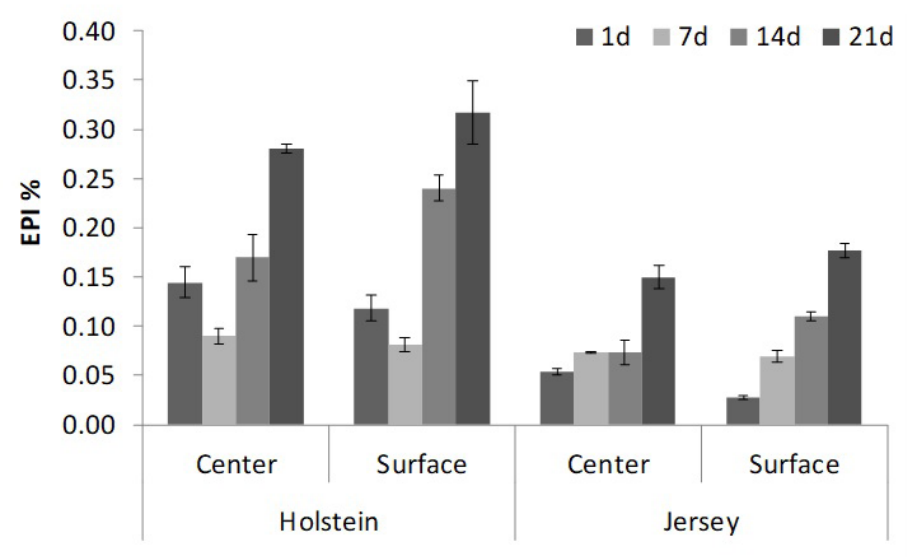

(a)

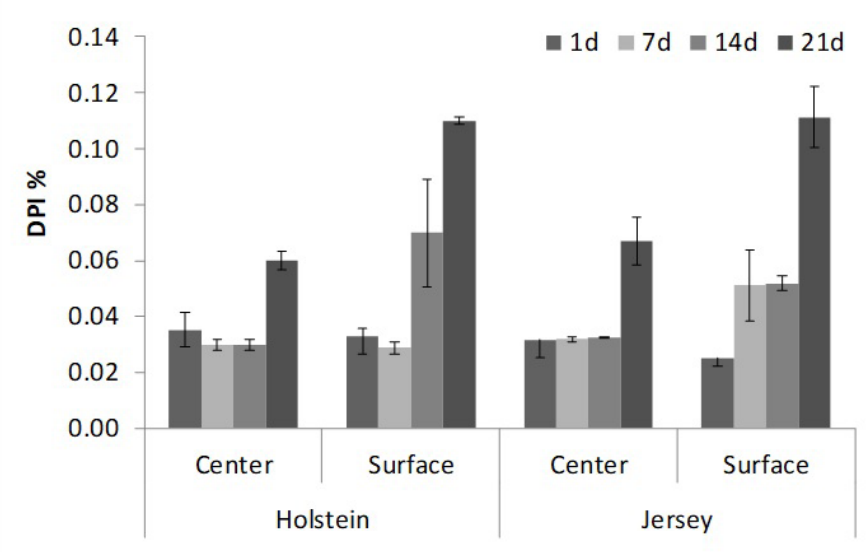

(b)

Figure 1. Evolution of the extent of proteolysis index, EPI (a) and depth of proteolysis index, DPI (b). 
Jaster et al.

Table 2. Texture profile of ripening cheese by G. candidum elaborated with cow milk breeds Holstein and Jersey.

\begin{tabular}{|c|c|c|c|c|c|c|}
\hline \multirow{2}{*}{ Parameter } & \multirow{2}{*}{ Dairy cows } & \multicolumn{4}{|c|}{ Period of ripening (days) } & \multirow{2}{*}{$p$} \\
\hline & & 1 & 7 & 14 & 21 & \\
\hline \multirow[t]{2}{*}{ Hardness (N) } & Holstein & $10 \pm 2^{\mathrm{aA}}$ & $7.60 \pm 1.23^{\mathrm{bA}}$ & $2.32 \pm 0.71^{\mathrm{cA}}$ & $1.5 \pm 0.6^{c}$ & * \\
\hline & Jersey & $6.34 \pm 0.80^{\mathrm{aB}}$ & $1.71 \pm 0.51^{\mathrm{abB}}$ & $1.49 \pm 0.28^{\mathrm{bB}}$ & $1.3 \pm 0.3^{\mathrm{b}}$ & * \\
\hline \multirow[t]{2}{*}{ Springiness } & Holstein & $0.89 \pm 0.01^{\mathrm{a}}$ & $0.88 \pm 0.01^{\mathrm{aA}}$ & $0.80 \pm 0.06^{\mathrm{b}}$ & $0.7 \pm 0.2^{\mathrm{b}}$ & * \\
\hline & Jersey & $0.88 \pm 0.02^{\mathrm{a}}$ & $0.83 \pm 0.01^{\mathrm{abB}}$ & $0.77 \pm 0.01^{\mathrm{b}}$ & $0.69 \pm 0.05^{\mathrm{b}}$ & * \\
\hline Cohesiveness & Jersey & $0.82 \pm 0.01^{\mathrm{aB}}$ & $0.79 \pm 0.01^{\mathrm{abB}}$ & $0.73 \pm 0.01^{\mathrm{b}}$ & $0.66 \pm 0.05^{\mathrm{b}}$ & * \\
\hline$P$ & & * & * & ns & ns & \\
\hline \multirow[t]{2}{*}{ Gumminess $(\mathrm{N})$} & Holstein & $8.41 \pm 1.24^{\mathrm{aA}}$ & $6.16 \pm 0.13^{\mathrm{bA}}$ & $1.8 \pm 0.6^{\mathrm{cA}}$ & $1.1 \pm 0.6^{c}$ & * \\
\hline & Jersey & $5.17 \pm 0.64^{\mathrm{aB}}$ & $1.35 \pm 0.40^{\mathrm{abB}}$ & $1.1 \pm 0.2^{\mathrm{bB}}$ & $0.9 \pm 0.3^{\mathrm{b}}$ & * \\
\hline$P$ & & * & * & * & ns & \\
\hline Resilience & Jersey & $0.45 \pm 0.01^{\mathrm{aB}}$ & $0.45 \pm 0.01^{\mathrm{aB}}$ & $0.34 \pm 0.01^{\mathrm{abB}}$ & $0.27 \pm 0.03^{b}$ & * \\
\hline$P$ & & * & * & * & ns & \\
\hline
\end{tabular}

Note: Different lowercase letters in the same row indicate significant differences between days of ripening (Test t, ${ }^{*} p<0.05$ ). Different capital letters in the same column indicate significant differences between cheeses elaborated with cow milk breeds Holstein and Jersey (Fisher’s test, ${ }^{*} p<0.05$ ). ns: indicates no significant difference.

Table 3. Colorimetric analysis of the surface and center of ripened cheese by G. candidum elaborated with cow milk of Holstein and Jersey breeds.

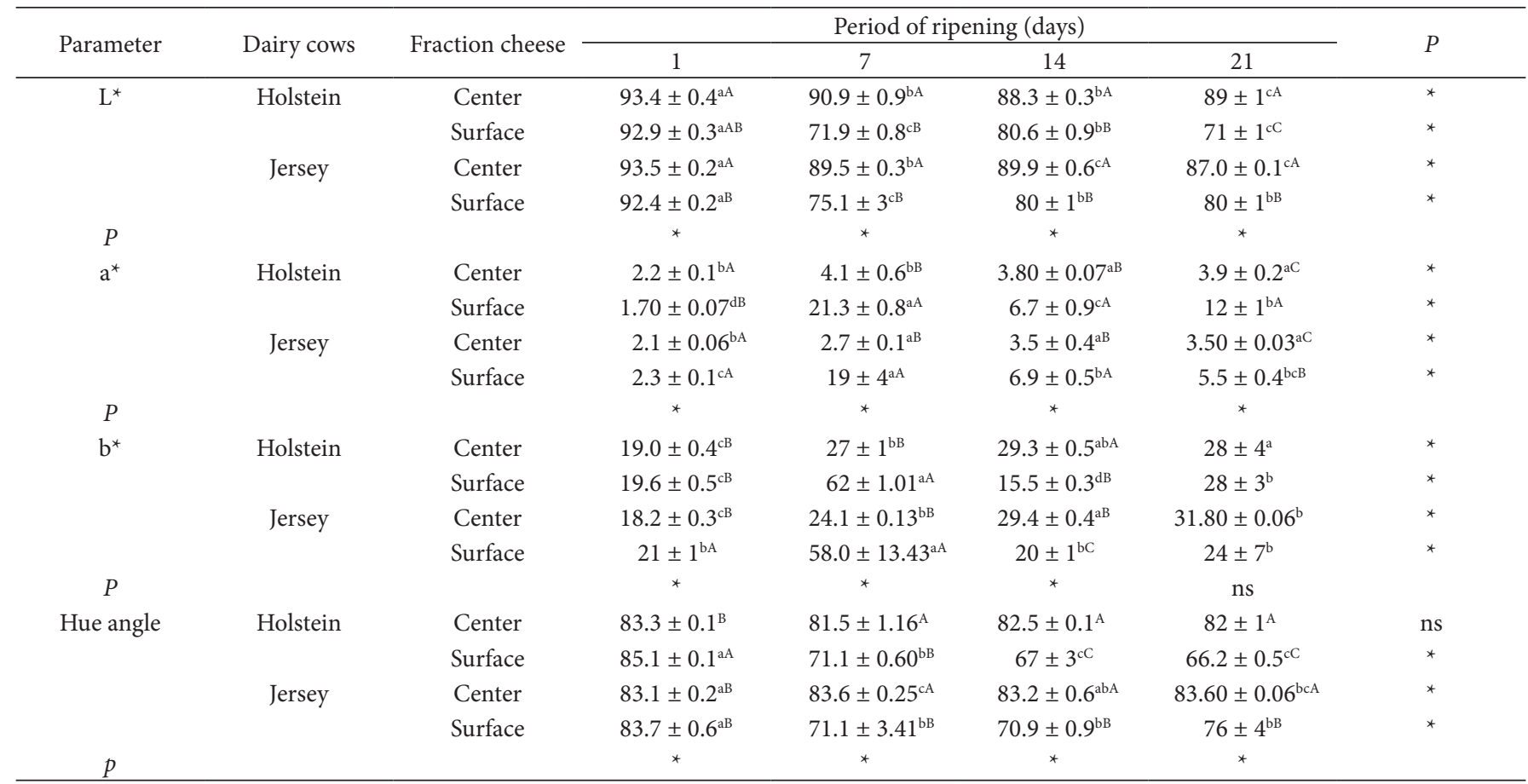

Note: Different lowercase letters in the same row indicate significant differences between days of ripening (Fisher's test, $\left.{ }^{*} p<0.05\right)$. Different capital letters in the same column indicate significant differences between cheeses elaborated with cow milk breeds Holstein and Jersey (Fisher's test, $\left.{ }^{*} p<0.05\right)$. L: luminosity; $a^{\star}$ : color parameter red (+) and green $(-)$; $b^{\star}:$ color parameter yellow (+) and blue (-); ns: indicates no significant difference.

\subsection{Multivariate analysis}

Multivariate tools were used to evaluate all the variables together and to determine their main effects on the cheeses. Principal component analysis (PCA) was applied to evaluate the physico-chemical, texture and instrumental color of the cheeses during ripening by G. candidum. Using a 2D-scatter plot it was possible to distinguish the cheeses according to the ripening stage and the breed of cow. The first principal component (PC1) was able to explain up to $46.25 \%$ of variance and PC2 could explain $21.08 \%$, totaling $67.33 \%$ of total variance (Figure 2). 
Hartmann et al. (2015) evaluated the thermo-physical parameters of generic Emmental cheese from Germany, the use of PCA explained $68.9 \%$ of total variance and when considering the three first PC's they concluded that the thermo-physical properties were suitable for the characterization of Emmental cheese.

In the present study, the similarity between the samples was assessed by hierarchical cluster analysis (HCA) and three clusters were suggested, which corroborated with the groups obtained by PCA. Cluster 1 grouped together the fresh cheeses (located on the left side) (Figure 2) and differences between the cow breeds were reflected in higher levels of luminosity (center e surface), hue angle $\left(h^{\star}\right)$ (surface), hardness, springiness, gumminess, and

A
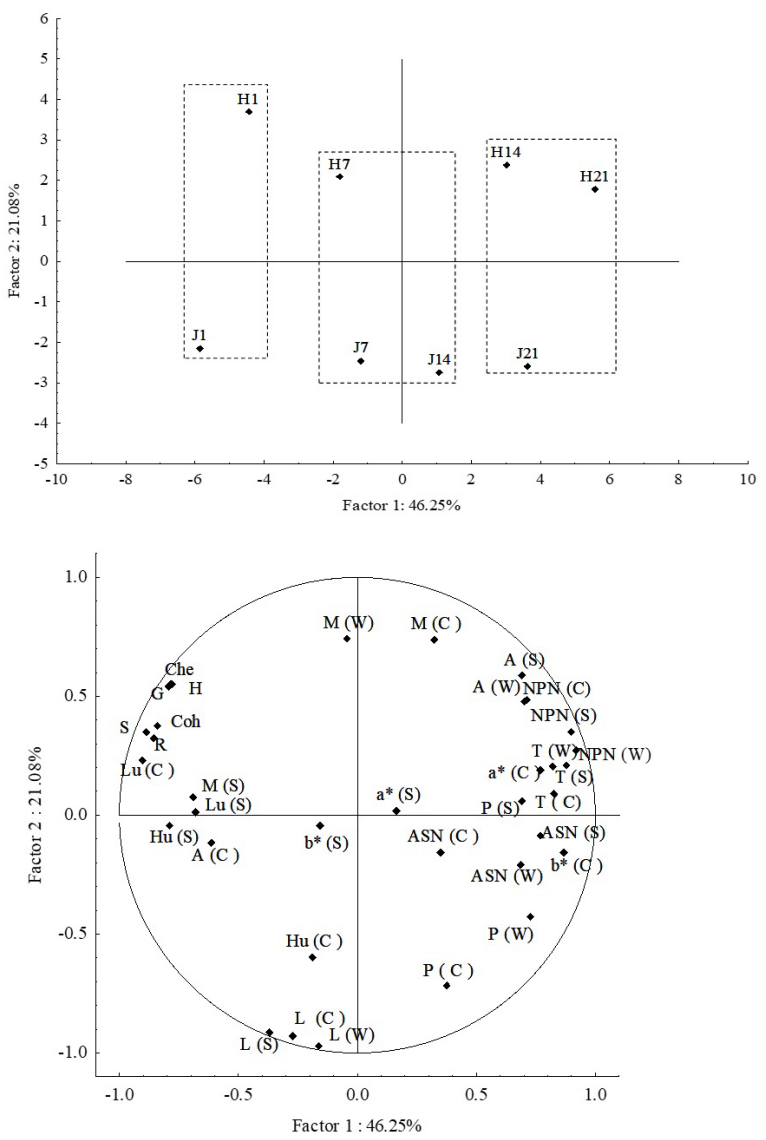

Figure 2. Principal component analysis (PCA): (A) PCA scores plot; (B) scatter loading plots. Note: $\mathrm{M}(\mathrm{C})$ - Moisture (center); M(S)- Moisture (surface); M(W)- Moisture (whole); A(C)- Ash (center); A(S)- Ash (surface); A(W)- Ash (whole); L(C)- Lipids (center); L(S)- Lipids (surface); L(W)- Lipids (whole); NPN(C)- Non-protein nitrogen (center); NPN (S)- Non-protein nitrogen (surface); NPN (W)- Non-protein nitrogen (whole); ASN (C)- Nitrogen soluble acid (center); ASN (S)- Nitrogen soluble acid (surface); ASN (W)- Nitrogen soluble acid (whole); $\mathrm{T}(\mathrm{C})$ - Tyrosine (center); $\mathrm{T}(\mathrm{S})$ - Tyrosine (surface); $\mathrm{T}(\mathrm{W})$ - Tyrosine (whole); Lu (C)- Luminosity (center); LU (S)- Luminosity (surface); $\mathrm{a}^{\star}(\mathrm{C})$ - color parameter red $(+)$ and green $(-)$ (center); $\mathrm{a}^{\star}(\mathrm{S})$ - color parameter red $(+)$ and green $(-)\left(\right.$ Surface); $b^{\star}(C)$ - color parameter yellow (+) and blue (-) (center); $b^{\star}(S)$ - color parameter yellow (+) and blue (-) (Surface); Hu (C) - Hue Angle (center); Hu (S) - Hue Angle (Surface); H- Hardness; S - Springiness; Coh - Cohesiveness; G - Gumminess; Che - Chewiness; R- Resilience. chewiness. Cluster 2 (located in the center) was characterized by higher levels of ashes (surface), lipids (whole) from Jersey milk (Table 1), and Holstein milk cheese with seven days of ripening, with higher levels of moisture (whole) (Table 1), soluble nitrogen (surface), hardness, gumminess and chewiness. The cheeses produced with Jersey cow's milk with 21 days of ripening and from Holstein cow's milk with 14 and 21 days of ripening were clustered in the same group (Cluster 3 , located to the right). In this cluster, higher levels of ash (surface), protein (whole), NPN (surface, center and whole), ASN (surface), tyrosine (surface, center and whole), $a^{*}$ (center and surface) and $b^{*}$ (center) were observed. Cluster 3 also gathered together the ripest cheeses, with higher proteolysis and lower values for the texture parameters (hardness, springiness, cohesiveness, gumminess, chewiness and resilience). In addition to PCA and HCA, two-way ANOVA was performed to confirm the effects of the cows breeds and the period of ripening on the cheeses. The cow's breeds showed a significant effect $(p<0.05)$ for all the physico-chemical variables, except for colorimetric analysis $\left(b^{*}\right)$. It should be remembered that the colorimetric parameters for this kind of cheese are influenced by the colorant that is applied to the cheese during ripening.

The effect of the ripening period was significant for all the variables $(p<0.05)$, with the exception for moisture content. The effect of the interaction between the cow breeds and the period of ripening on the quality of the cheeses during ripening by $G$. candidum were also evaluated. They were significant $(p<0.05)$ for hardness, cohesiveness, gumminess, chewiness, resilience, $L^{*}, a^{*}$, hue angle, lipids, non-protein nitrogen, acid soluble nitrogen and tyrosine, which emphasized the interaction between the period of ripening and the type of milk.

\section{Conclusion}

This article describes a new manufacturing protocol and composition characteristics of a new ripened soft cheese by G. candidum. The manufacture cheese using Holstein and Jersey cow milks showed significant effects $(p<0.05)$ on the physico-chemical and instrumental parameters during the ripening period. This was confirmed by multivariate analysis, which was an efficient tool to identify the differences. Proteolysis was higher in the cheese made with Holstein cow milk. However, the cheeses manufactured with Jersey cow milk were influenced in terms of the moisture and fat content and there was a direct effect on the texture profile. The identity characteristics of cheese ripened by G. candidum occurred after 14 days of ripening due to changes in the composition of the cheese and in its sections (rind and center). This cheese can be consumed in natura (manufactured mainly with Jersey milk) or be used in the gastronomy (manufactured with Holstein milk) with 21 days of ripening. After 25 days of ripening, both the cheeses can be used preferentially in the gastronomy.

\section{Acknowledgements}

The authors are grateful to the National Council for Scientific and Technological Development (CNPq), the Secretary of State of Higher Education, Science and Technology (SETI/PR) and the 
Coordination for the Improvement Personnel in Higher Level (CAPES) for financial support and scholarships.

\section{References}

Association of Official Analytical Chemists International - AOAC. (2016). Official Methods of Analysis of the Association of Official Analytical Chemistry (20th ed.). Washington: AOAC International.

Aziza, M., Adour, L., \& Amrane, A. (2008). Energy substrate efficiency during batch cultures of Geotrichum candidum. Journal of the Science of Food and Agriculture, 88(6), 984-988. http://dx.doi.org/10.1002/ jsfa.3178.

Bastian, E. D., Brown, R. J., \& Ernstrom, C. A. (1991). Plasmin activity and milk coagulation. Journal of Dairy Science, 74(11), 3677-3685. http://dx.doi.org/10.3168/jds.S0022-0302(91)78557-3.

Blake, R. W., Custodio, A. A., \& Howard, W. H. (2012). Comparative feed efficiency of Holstein and Jersey cows. Journal of Dairy Science, 69(5), 1302-1308. http://dx.doi.org/10.3168/jds.S0022-0302(86)805367. PMid:3722546.

Boutrou, R., \& Guéguen, M. (2005). Interests in Geotrichum candidum for cheese technology. International Journal of Food Microbiology, 102(1), 1-20. http://dx.doi.org/10.1016/j.ijfoodmicro.2004.12.028. PMid:15924999.

Boutrou, R., Kerriou, L., \& Gassi, J.-Y. (2006). Contribution of Geotrichum candidum to the proteolysis of soft cheese. International Dairy Journal, 16(7), 775-783. http://dx.doi.org/10.1016/j.idairyj.2005.07.007.

Bylund, G. (2015). Dairy processing handbook. Sweden: Tetra Pak Processing Systems AB.

Castellote, J., Fraud, S., Irlinger, F., Swennen, D., Fer, F., Bonnarme, P., \& Monnet, C. (2015). Investigation of Geotrichum candidum gene expression during the ripening Reblochon-type cheese by reverse transcription quantitative PCR. International Journal of Food Microbiology, 194, 54-61. http://dx.doi.org/10.1016/j. ijfoodmicro.2014.11.009. PMid:25461609.

Cogan, T. M., Goerges, S., Gelsomino, R., Larpin, S., Hohenegger, M., Bora, N., Jamet, E., Rea, M. C., Mounier, J., Vancanneyt, M., Guéguen, M., Desmasures, N., Swings, J., Goodfellow, M., Ward, A. C., Sebastiani, H., Irlinger, F., Chamba, J. F., Beduhn, R., \& Scherer, S. (2014). Biodiversity of the surface microbial consortia from Limburger, Reblochon, Livarot, Tilsit, and Gubbeen cheeses. Microbiology Spectrum, 2(1), 2010-2012. http://dx.doi.org/10.1128/ microbiolspec.CM-0010-2012. PMid:26082119.

De Rensis, C. M. V. B., Petenate, A. J., \& Viotto, W. H. (2009). Chemical composition, rheological and sensorial characterization of reduced fat Prato cheese. Food Science and Technology, 29(3), 488-494. http:// dx.doi.org/10.1590/S0101-20612009000300005.

Denis, T. S., Humbert, G., \& Gaillard, J.-L. (2001). Heat inactivation of native plasmin, plasminogen and plasminogen activators in bovine milk: a revisited study. Le Lait, 81(6), 715-729. http://dx.doi. org/10.1051/lait:2001159.

Dufossé, L., Galaup, P., Carlet, E., Flamin, C., \& Valla, A. (2005). Spectrocolorimetry in the CIE $\mathrm{L}^{*} \mathrm{a}^{*} \mathrm{~b}^{*}$ color space as useful tool for monitoring the ripening process and the quality of PDO red-smear soft cheeses. Food Research International, 38(8-9), 919-924. http:// dx.doi.org/10.1016/j.foodres.2005.02.013.

France. Ministère de L'Agriculture ET de La Pêche. (2008). Décrets, arrêtés, circulaires. Décret n ${ }^{\circ} 2008-984$ du 18 septembre 2008. Relatif à l'appellation d'origine contrôlée «Camembert de Normandie». Jounal Officiel de La Republique Française, 15 p.
Hartmann, K. I., Samudrala, R., Hofmann, T., Schieberle, P., Hitzmann, B., \& Hinrichs, J. (2015). Thermo-physical parameters applied for instrumental profiling and statistical evaluation of German Emmental cheese. International Dairy Journal, 49, 118-124. http:// dx.doi.org/10.1016/j.idairyj.2015.05.004.

Instituto Adolfo Lutz - IAL. (2008). Methods for physical and chemical analysis of foods (4th ed.). Brasília: Ministério da Saúde, Agência Nacional de Vigilância Sanitária.

Larpin, S., Mondoloni, C., Goerges, S., Vernoux, J. P., Guéguen, M., \& Desmasures, N. (2006). Geotrichum candidum dominates in yeast population dynamics in Livarot, a French red-smear cheese. FEMS Yeast Research, 6(8), 1243-1253. http://dx.doi.org/10.1111/j.15671364.2006.00127.x. PMid:17156021.

Lynch, J. M., \& Barbano, D. M. (1999). Kjeldahl nitrogen analysis as a reference method for protein determination in dairy products. Journal of AOAC International, 82(6), 1389-1398. PMid:10589493.

Marcellino, N., Beuvier, E., Grappin, R., Gueguen, M., \& Benson, D. R. (2001). Diversity of Geotrichum candidum strains isolated from traditional cheesemaking fabrications in France. Applied and Environmental Microbiology, 67(10), 4752-4759. http://dx.doi. org/10.1128/AEM.67.10.4752-4759.2001. PMid:11571181.

Marinho, M. T., Zielinski, A. A., Demiate, I. M., Bersot, L. S., Granato, D., \& Nogueira, A. (2015). Ripened semihard cheese covered with lard and dehydrated rosemary (Rosmarinus officinalis L.) leaves: processing, characterization, and quality traits. Journal of Food Science, 80(9), S2045-S2054. http://dx.doi.org/10.1111/1750-3841.12988. PMid:26259705.

Martin, B., Chamba, J. F., Coulon, J. B., \& Perreard, E. (1997). Effect of milk chemical composition and clotting characteristics on chemical and sensory properties of Reblochon de Savoie cheese. The Journal of Dairy Research, 64(1), 157-162. http://dx.doi.org/10.1017/ S0022029996001975.

McSweeney, P. L. H. (2017). Biochemistry of cheese ripening: introduction and overview. In P. F. Fox, P. L. H. McSweeney, T. M. Cogan \& T. P. Guinee (Eds.), Cheese: chemistry, physics and microbiology: general aspects (4th ed., pp. 379-387). London: Academic Press. http:// dx.doi.org/10.1016/B978-0-12-417012-4.00014-4.

Molimard, P., Vassal, L., Bouvier, I., \& Spinnler, H. E. (1995). Suivi de croissance de Penicillium camemberti et Geotrichum candidum en culture pure et en association au cours de l'affinage de fromages expérimentaux à pâte molle de type camembert. Le Lait, 75(1), 3-16. http://dx.doi.org/10.1051/lait:199511.

Monnet, C., Landaud, S., Bonnarme, P., \& Swennen, D. (2015). Growth and adaptation of microorganisms on the cheese surface. FEMS Microbiology Letters, 362(1), 1-9. PMid:25790503.

Mourgues, R., Bergère, J. L., \& Vassal, L. (1983). Possibilité d'améliorer les qualités organoleptiques des fromages de camembert grâce à l'utilisation de Geotrichum candidum. Le Lait, 978, 11-15.

Pottier, I., Gente, S., Vernoux, J.-P., \& Guéguen, M. (2008). Safety assessment of dairy microorganisms: Geotrichum candidum. International Journal of Food Microbiology, 126(3), 327-332. http:// dx.doi.org/10.1016/j.ijfoodmicro.2007.08.021. PMid:17869364.

Sacristán, N., González, L., Castro, J. M., Fresno, J. M., \& Tornadijo, M. E. (2012). Technological characterization of Geotrichum candidum strains isolated from a traditional Spanish goats' milk cheese. Food Microbiology, 30(1), 260-266. http://dx.doi.org/10.1016/j. fm.2011.10.003. PMid:22265310. 
Schaar, J. (1985). Plasmin activity and proteose-peptone content of individual milks. The Journal of Dairy Research, 52(3), 369-378. http://dx.doi.org/10.1017/S0022029900024274.

Vakaleris, D. G., \& Price, W. V. (1959). A Rapid spectrophotometric method for measuring cheese ripening. Journal of Dairy Science, 42(2), 264-276. http://dx.doi.org/10.3168/jds.S0022-0302(59)90562-4.

Van den Tempel, T., \& Nielsen, M. S. (2000). Effects of atmospheric conditions, $\mathrm{NaCl}$ and $\mathrm{pH}$ on growth and interactions between moulds and yeasts related to blue cheese production. International Journal of Food Microbiology, 57(3), 193-199. http://dx.doi.org/10.1016/ S0168-1605(00)00263-4. PMid:10868680.
Wadhwani, R., \& Mcmahon, D. J. (2012). Color of low-fat cheese influences flavor perception and consumer liking. Journal of Dairy Science, 95(5), 2336-2346. http://dx.doi.org/10.3168/jds.2011-5142. PMid:22541462.

Zielinski, A. A. F., Haminiuk, C. W. I., Nunes, C. A., Schnitzler, E., van Ruth, S. M., \& Granato, D. (2014). Chemical composition, sensory properties, provenance, and bioactivity of fruit juices as assessed by chemometrics: a critical review and guideline. Comprehensive Reviews in Food Science and Food Safety, 13(3), 300-316. http:// dx.doi.org/10.1111/1541-4337.12060. 